\title{
The utilization of journalistic sources in the national press: Communicating the transition from economic crisis to sustainable growth ${ }^{*}$
}

\author{
प⿴囗十口प⿴囗十 \\ Theodora Maniou \\ Irene Photiou \\ Nikleia Eteokleous \\ loannis Seitanidis
}

FREDERICK UNIVERISTY OF CYPRUS \& OPEN UNIVERSITY OF CYPRUS, CYPrUS

DOI: 10.19195/1899-5101.10.1(18).7

\begin{abstract}
This paper discusses the role and utilization of journalistic sources in the process of communicating the transitional path of a society in crisis towards economic and sustainable growth. It is mainly concerned with the general tendency of the press to display a high degree of manipulation of public opinion by reduction of the diversity of sources and/or their misuse. Cyprus was selected as a case study not only because newspapers still play a dominant role in shaping public opinion in contrast to New Media, but also because sustainable growth has been the basic argument and rhetoric in governmental communication policy, which promoted it as one of the main means in overcoming the ongoing economic/banking crisis the country has been facing since the bailout of the banking sector in 2013. The aim of this research is to examine which categories of journalistic sources shape this topic in the current public sphere and the way(s) journalists perceive and practice the utilization of their sources. Content analysis has been employed as the basic methodological tool, while a questionnaire survey on journalists of the national press was additionally conducted in order to explain these findings and conclude the study.
\end{abstract}

KEYWORDS: press, journalistic sources, sustainable growth, Cyprus.

\section{INTRODUCTION}

The ongoing economic crisis has induced significant changes in all strata of society. Equally powerful changes have occurred in the reportages published in the national press, which had substantive repercussions in the shaping of the contempor-

This publication is based on national data regarding Cyprus, which emerged during the course of the research project "Journalistic Role Performances around the Globe". 
ary public sphere and, consequently, of the public dialog. This paper discusses the role and utilization of journalistic sources in the process of communicating the transitional path of a society in crisis towards economic and sustainable growth. It is mainly concerned with the general tendency of the press to display a high degree of manipulation of the public opinion by reduction of the diversity of sources and/ or their misuse.

Cyprus was selected as a case study not only because newspapers still play a dominant role in shaping the public opinion in contrast to the New Media, but also because sustainable growth has been the basic argument and rhetoric in governmental communication policy, which promoted it as one of the main means in overcoming the ongoing economic/banking crisis the country has been facing since the bailout of the banking sector in 2013. The attempts to stabilize the Cypriot banking system and to shape a new, sustainable and efficient social archetype, independent of financial services from the banks, comprise elements of considerable problematization, which have infused the topics reported by the press. The subjection of the country to a program of adjustment of the public sector and funding by the Troica has led to structural changes, both in production and the economy, readjusting existing social and political relationships. This paper examines the content of Greek-Cypriot newspapers on matters of sustainable growth during the year 2013, which marked the peak of the banking crisis in the country. The aim of this research is to examine which categories of journalistic sources shape this topic in the current public sphere and the way(s) journalists perceive and practice the utilization of their sources. Content analysis has been employed as the basic methodological tool, while a questionnaire survey on journalists of the national press was additionally conducted in order to explain these findings and conclude the study.

\section{THE RELATION OF THE PRESS WITH PRIMARY AND SECONDARY JOURNALISTIC SOURCES}

Researchers tend to agree that the practice of information and the mass media themselves have changed radically in recent years (Spiteri, 2009; see also Curtin \& Rhodenbaugh, 2001; Witschge \& Nygren, 2009). The Internet permits the circumvention of traditional mass media and professional journalists, that is, the formal institutions, in the production and communication of news. On the other hand, offices of public relations, which have been institutionalized in every private company, lobbies and special-interest groups (e.g., unions, employers groups and trusts, environmental groups, etc.) both create news stories, as well as intervene and participate in the process of information of the public (Spiteri, 2009). Since nowadays the origin of the news may lie with every citizen or organized group, the review of media sources cannot be limited to their simple listing (as primary or secondary), but it is of equal importance to discuss their credibility.

Journalists consider (and treat) as primary sources international news agencies, civic sources (e.g., civil servants, the police, etc.), governmental sources (e.g., state 
officials and ministries), as well as political and partisan sources (Curtin \& Rhodenbaugh, 2001; Kollmeyer, 2004; Lewis, 2000; Spiteri, 2009). News agencies still comprise the first reference point for the collection of information on news stories, since they relay news summaries devoid of any comments, a fact that adds to their credibility (Spiteri, 2009, pp. 133-135). The relationship of news agencies with their "customer" journalists, however, is almost a monopoly, resulting in suspicion and criticism of the news being especially shaped for consumption in the media (p. 138).

In parallel to news agencies, journalists tend to collect information from "de facto accredited sources", as they consider civil servants, government sources and other political or party sources, documents and essays originating from civic desks, formal announcements of civil servants and officers, the research of parliamentary committees, etc. (pp. 139-140). For example, various studies conducted between 1974 and 2001, regarding the reference of environmental topics in US media, find that the vast majority of journalists prefer citing governmental sources, as neutral and therefore credible (Witt, 1974; Griffin \& Dunwoody, 1995; Lacy \& Coulson, 2000; Curtin \& Rhodenbaugh, 2001). Another notable example is the media transmission of news regarding sustainable growth in local communities in Spain, information for which seems to be originating almost entirely from the political parties in authority, and which (naturally) serve their political interests (Cuadrado-Ballesteros et al., 2014).

In recent years, there is a large number of auxiliary or secondary sources in the public sphere. The internet and modern communication technologies have become the platforms for so-called citizen journalism, providing the means for every user to publish information in these new media and thus contribute actively in the communication of information. The immediacy of the Internet has thus changed the flow of information to the public sphere (Hermans \& Vergeer, 2009; Leandros, 2012a; Maniou, 2013). With the proficiency of the internet in the collection and dissemination of information no longer in doubt, professional journalists now frequently tend to incorporate it in their practices of gathering and producing news (Hermans \& Vergeer, 2009; Quinn, 1999; Trumbo et al., 2001). Finally, complementary sources include experts who specialize in particular fields of skill and knowledge that directly relate to particular news stories (e.g., academics, medical personnel, consultants), public opinion polls regarding crucial issues, as well as (eye-witness) testimonies of individuals on topics of current affairs, given in biographies, roundtable talks (Spiteri, 2009), or directly through the aforementioned media.

In most cases, journalists practice a "routine" in collecting information and evidence for a news item, mostly amassing their material from a specific number of primary sources (Kollmeyer, 2004). This "routine" may be the consequence of their need to maximize their efficiency, but it may result in sidelining the information arising from secondary sources (Spiteri, 2009; Kollmeyer, 2004; Herman \& Chomsky, 2002), which, because of this, may indirectly be underestimated or undermined. 
"Routine" practices in collecting information generate the fundamental debate whether the professionals of the media are "under the custody of the governmental or civic services and whether they are doomed to broadcast institutionalized declarations" (Spiteri, 2009, p. 140). Proponents of this position support that the limited origins of the news, entirely or at least mainly from institutional sources, definitionally result in the presentation of specific sides only, while avoiding broader representation (Lewis, 2000). In fact, considering that the mass media themselves are profit-seeking entities, it could be (and frequently is) claimed that it is in their financial interests to support specific positions on sensitive issues, such as politics, the economy, etc. That is, it could be claimed that the media provide a platform to those groups who are willing "to play by the rules" of the existing status-quo in social power relations (p. 268). Furthermore, since the information that establishes a story is provided by (a) particular source(s), it is in its/their best interests to publicize only the material that it/they desire. Therefore, the train of thought that the communication of a news item is not actually information of the public, but rather a double manipulation (the source(s) manipulate the journalist, and the journalist the public), does seem logical (Spiteri, 2009, p. 235).

Critics of the above position argue that formal primary sources present important, verified information, which is useful to be transmitted by journalists, while secondary sources may reproduce inconsistencies, contradictory opinions or may themselves serve specific agendas. They also claim that primary sources cannot know in advance how the media will interpret the news and what (if any) criticism will be exercised on them, so it is only skepticism that leads to the idea that journalists are simply mouthpieces for specific primary sources and their agendas (pp. 140141). Finally, one could argue that if the information communicated by primary sources to the public via the media is suspect, then the information provided willingly by secondary sources has to be (at least) equally suspect. Consequently, one wonders whether it is true that pure information can only exist through those facts that no source wants to publicize (Spiteri, 2009, p. 235).

\section{THE ROLE OF THE PRESS IN THE TRANSITION TOWARDS SUSTAINABLE GROWTH}

The concept of sustainability in the economy appeared in the 1970s, during which the oil crisis and recession were linked to the downgrading of environmental issues and the overuse of natural resources. In 1987, the World Commission on Environment and Development (WCED), led by former Norwegian Prime-Minister, Gro Harlem Brundtland, defined "sustainable development" as the development that meets the needs of the present without compromising the ability of future generations to satisfy their own needs (Byrch et al., 2007).

During the United Nations Conference in Rio in 1992, the "Rio Declaration on Environment and Development" and "Agenda 21" were both signed, binding 170 nations to employ the philosophy of sustainable growth as a fundamental concept 
in their future development. The financial crisis of 2008 resulted in allotting the concept of sustainable growth a new dimension. The International Monetary Fund has proclaimed this crisis as the most pronounced one since the Great Depression of the 1930s. The advanced economies of the world have experienced a much greater shock than was speculated possible in the past, and the provision of government support to the banking sector has exacerbated the national debt crisis (IMF, 2014, p. 36). The encumbrance of national budgets with the rescue and subsidization of banking institutions has led to the implementation of new policies, which are reflected in the decisions of the 20 largest economies in the world (G20). The declaration of the G20 Toronto Summit (2010) noted that "recent events highlight the importance of sustainable public finances and the need for our countries to put in place credible, properly phased and growth-friendly plans to deliver fiscal sustainability, differentiated for and tailored to national circumstances".

Sustainable growth is now synonymous with viable national economies. However, opinions vary considerably on the mechanics of this subject. The approach of "austerity counterweight" promotes the consolidation of public debt and structural reforms, in order to restore trust in the market, improve the competitiveness of the economy and attract investments. "The mechanism through which an economy can achieve 'return to growth' is supposedly simple. Fiscal consolidation and structural reform will restore confidence in the market, improve the competitiveness of the economy and attract investment" (Leandros, 2012b, p. 401). This interpretation is clearly imprinted in the programs of economic adjustment that have been implemented in Greece, Ireland, Portugal, and Cyprus, as well as the political measures employed in the Baltic countries. In this method, growth is considered sustainable when it does not depend on the generation of new debt, but on the reinforcement of competition and productivity. However, its exacerbation of various financial, social and environmental problems brings to bear, with increasingly greater intensity, the issue of changing the way we conceive of growth (p. 306).

The examination of media representations of sustainable growth is usually framed by criticisms of this concept. At the present time, the attention of the media is focused mainly on subjects related to the financial crisis. However, a strong correlation has been found between the role of the press and actions undertaken during periods of crisis, and to a certain degree, the media have even influenced the level of acceptance of certain policies (Bloch-Elkon, 2007; Lee, 1999).

At the same time, professional journalists are subject to the responsibility of ensuring that the positions and opinions of various groups and individuals are duly represented in the mass media and that citizens have access to sufficient information in order to form well-reasoned views regarding social issues (Wilenius \& Malmelin, 2009). In fact, before the manifestation of the financial crisis, the European Parliament recognized that freedom of expression, including freedom of the press and the laws which govern the access to information, are critical measures in sub- 
duing corruption, which has dire consequences on the development and achievement of the aims of growth in the entire world (European Parliament Resolution regarding growth and the media). In the same document, it is highlighted that freedom of the media is necessary to maintain social stability, the notion of good governance and financial progress. In the reasoning of the resolution, it is noted that "the media can help a country's development, because people's quality of life can be affected by ICT ('information and communication technologies')" and that "the media can have a positive influence on people's mentality, culture, and the socio-political apparatus; and the shaping of the civil and political consciousness of citizens could lead to more representative government" (European Parliament Resolution regarding growth and the media).

\section{A BRIEF ACCOUNT OF THE BANKING CRISIS IN CYPRUS}

The Republic of Cyprus has suffered through various crises since it was established in 1960, although most were linked to politics and, after 1974, its main national problem: the occupation of northern Cyprus by Turkish troops. Despite these, during the 1980s and 1990s, Cyprus was considered a tax haven, attracting considerable sums from foreign direct investors, mostly, but not exclusively, of Russian interests (Charalambous, 2014). The banking and financial sector expanded swiftly, and by 2010 its volume in terms of capital was almost 8 times national GDP (Stefanou, 2011).

However, it was exactly this rapid growth which, in March 2013, led the Eurogroup to reach an unprecedented decision regarding the Cypriot financial crisis (already evident since 2011), as well as the Eurozone more broadly. ${ }^{1}$ This decision called for the participation of the public in the financial bailout of its banks and the country's economy. Although the initial proposal was designed to penalize small savers as well, the plan that was eventually adopted imposed a haircut on deposits above 100,000 euro (Charalambous, 2014).

Thus, in March 2013 a Memorandum of Understanding (MoU) was signed between the Cypriot government and the Troica, which supplemented the bailout funds (both foreign and local) with a chain of austerity measures similar to those imposed on Greece, Spain, and Portugal. The final Cyprus Economic Adjustment Programme, endorsed by the House of Representatives on 30 April 2013, includes a number of conditions, activated by the Troica's MoU: the recapitalization of the entire financial sector while accepting the closure of the Laiki bank, the implementation of an anti-money laundering framework in Cypriot financial institutions, fiscal consolidation to help decrease the Cypriot budget deficit, structural reforms

1 It is not the immediate goal of this paper to analyse the financial reasons that led to the banking crisis of 2013, or to provide an in-depth examination of how it occurred. 
to restore competitiveness and macroeconomic imbalances, and a privatization programme targeting semi-governmental organizations (Charalambous, 2014).

\section{RESEARCH METHODOLOGY, SAMPLE, RATIONALE AND ROS}

The aim of this research has been to examine the primary news sources that currently shape the public sphere on issues of sustainable growth, within the framework of the modern communications environment of the press. Reports regarding the economy, the environment, energy issues, education and training, infrastructure projects and health are all included in the field of sustainable growth. This research has begun with the aim of addressing the following research questions:

1. What are the origins (thematic, geographical and/or other) of the sources, which the reportages of the press on issues of sustainable growth depend on?

2. Which types/categories of sources dominate the national press in times of economic crisis?

3. How do journalists' perceptions on their utilization of sources compare to their actual daily practices?

The methodology employed is that of Formal Content Research Analysis, based on the news reports (reportages) of Greek-Cypriot newspapers during the year 2013. The analysis made use of samples of text and categorization models, aiming to recognize specific features of these texts (Pawson, 1995). The sample of newspapers was selected every month of the year 2013 following a simple mathematical sequence, based on the days of the week.

The data was produced by the quantitative analysis of the content. ${ }^{2}$ The unit of the analysis was the news item, defined as a single, continuous text comprising of lexical elements and accompanying non-verbal features (such as tables, images, etc.) on the same page and concerning the same subject matter (Mellado \& Lagos, 2014, p. 2095). Specific criteria on the form and visual presentation of each reportage were not set a priori, as the intention was to include as many units of analysis as possible in the research. In this framework, the research sample consists of units of analysis from the five newspapers with the highest circulation for the year 2013, specifically the newspapers Phileleftheros, Politis, Simerini, Charavgi, and Alithia. ${ }^{3}$ Among the newspapers included in the sample, Phileleftheros and Politis are considered mainstream, Alithia is considered right-wing, Simerini is attributed with center-right affiliations, while Charavgi is the formal medium of the left-wing party AKEL (PRIO Group, 2010). The final sample comprises 1183 reportages (news items), as presented in Table 1 below.

2 This research was conducted as part of a larger research project, "Journalistic Role Performance around the Globe" (JRP), which investigates journalistic role performances in 33 participating countries (http://www.journalisticperformance.org/) and is based on national data regarding Cyprus.

${ }^{3}$ http://www.sigmalive.com/inbusiness/news/services/118037. 
Table 1 . The sample of 1,183 reportages broken down by newspaper

\begin{tabular}{|l|c|}
\hline \multicolumn{1}{|c|}{ Newspaper } & Number of news items \\
\hline Alithia & 318 \\
\hline Charavgi & 190 \\
\hline Phileleftheros & 234 \\
\hline Politis & 274 \\
\hline Simerini & 167 \\
\hline Total & 1183 \\
\hline
\end{tabular}

In the course of the study, seven researchers were trained in the implementation process of a particular codebook, and a pre-test and post-test were conducted to ensure that the researchers comprehended the additional variables similarly (Mellado \& Lagos, 2014, pp. 2095-2096). The tests yielded the following figures using the form KRIPPENDORFF's ALPHA:

Overall inter-coder reliability: 0.89 (pre-test)

Overall inter-coder reliability: 0.93 (post-test)

Therefore, we considered our results valid and carried out their analysis and discussion ( $\$ 6$ and $\$ 7$ respectively). With regards to the statistical test, the limit of $\mathrm{p}$ value $<0.05$ was set, while we considered it necessary to conduct a $\mathrm{z}$ test, in order to assign priority by importance of the tested variables (limit set of a $\mathrm{z}$-value $>0$ ).

Additionally, the second level of this research included a questionnaire survey intended for the journalists who reported the specific news items measured in the content analysis, in order to examine their personal beliefs and their daily practices regarding the use of sources. Some demographic characteristics of the total sample of journalists ${ }^{4}$ are presented in Tables 2, 3 and 4.

Table 2. Journalists' gender

\begin{tabular}{|l|c|c|}
\cline { 2 - 3 } \multicolumn{1}{c|}{} & N & $\%$ \\
\hline Males & 22 & 46 \\
\hline Females & 26 & 54 \\
\hline Total & 48 & 100 \\
\hline
\end{tabular}

Table 3. Journalists' years of experience

\begin{tabular}{|l|r|c|}
\cline { 2 - 3 } \multicolumn{1}{c|}{} & $\mathrm{N}$ & $\%$ \\
\hline Up to 5 years & 11 & 22.9 \\
\hline Between 6 and 10 years & 8 & 16.6 \\
\hline Between 11 and 20 years & 19 & 39.5 \\
\hline More than 21 years & 10 & 21 \\
\hline Total & 48 & 100 \\
\hline
\end{tabular}

${ }^{4}$ It has to be noted that national newspapers in Cyprus are small editions - no more than 50 pages in the daily editions - occupying a limited number of journalists, $8-10$ average per newspaper. This is why the number of the journalists sample is limited to 48 . 
Table 4. Journalists' political beliefs

\begin{tabular}{|l|c|c|}
\cline { 2 - 3 } \multicolumn{1}{c|}{} & N & $\%$ \\
\hline Left-towards the Left & 19 & 39.2 \\
\hline Centre-mainstream & 12 & 25 \\
\hline Right-towards the Right & 18 & 35.8 \\
\hline Total & 48 & 100 \\
\hline
\end{tabular}

\section{FINDINGS AND DISCUSSION}

\section{Newspapers' Content}

Table 5 presents the thematic topics the reportages of the five newspapers focused on in 2013, as indicated by the content analysis. Highlighted in bold are the topics identified in $\$ 3$ as associated with sustainable growth. As Table 5 shows, Simerini and Phileleftheros devoted approximately $50 \%$ of their reportages in 2013 to themes linked to sustainable growth, while the other three newspapers devoted about a third to these subjects. Initially, then, we can ascertain that issues linked with sustainable growth played a dominant role in the reportages of the press. We note that this occurred at a time when the country was experiencing the peak of its banking crisis.

Table 5. Topics reported on in the five newspapers of the sample (\%)

\begin{tabular}{|l|c|c|c|c|c|}
\hline \multicolumn{1}{|c|}{ Topic } & Simerini & Alithia & Phileleftheros & Politis & Charavgi \\
\hline $\begin{array}{l}\text { Government/ } \\
\text { parliament }\end{array}$ & 1.8 & 9 & 6.8 & 43.1 & 4.4 \\
\hline Parties/elections & 7.2 & 8.5 & 7.3 & 3.1 & 17.9 \\
\hline Police reportage & 9.6 & 5.8 & 12 & 8.5 & 5.1 \\
\hline Judiciary issues & 4.8 & 5.3 & 5.1 & 3.5 & 8.4 \\
\hline $\begin{array}{l}\text { Defense/national } \\
\text { security }\end{array}$ & 11.4 & 10.1 & 10.3 & 5.7 & 1.5 \\
\hline $\begin{array}{l}\text { Economy/ } \\
\text { corporations }\end{array}$ & 23.5 & 23.3 & 16.2 & 12.6 & 23.4 \\
\hline Education/training & 5.4 & 4.2 & 4.7 & 4.7 & 4.7 \\
\hline $\begin{array}{l}\text { Energy/ } \\
\text { environment }\end{array}$ & 5.4 & 3.2 & 6.4 & 5 & 2.2 \\
\hline Transport & 3.4 & 4.8 & 7.3 & 1.6 & 3.3 \\
\hline $\begin{array}{l}\text { Infrastructure/ } \\
\text { projects }\end{array}$ & 1.2 & 1.6 & 1.3 & 0.9 & 2.2 \\
\hline Natural disasters & 7.2 & 3.7 & 8.5 & 2.5 & 2.6 \\
\hline Health & & & & 0.9 & 0.4 \\
\hline
\end{tabular}


The utilization of journalistic sources in the national press

\begin{tabular}{|l|c|c|c|c|c|}
\hline Religion/church & 2.4 & 1.6 & 0.9 & 0.3 & 0.4 \\
\hline Human rights & 0.6 & 2.1 & 1.7 & 0.6 & 1.8 \\
\hline $\begin{array}{l}\text { Demonstrations/ } \\
\text { protests }\end{array}$ & 0.6 & 2.1 & 0.9 & 0.9 & 3.6 \\
\hline Social problems & 6.6 & 7.9 & 6 & 0.9 & 1.8 \\
\hline Other topics & 3.9 & 4.2 & 0.3 & 5.2 & 16.3 \\
\hline Total & 100 & 100 & 100 & 100 & 100 \\
\hline
\end{tabular}

As illustrated in Table 6, all five newspapers exhibited a preference for domestic/ national sources to acquire their information for the reportages on sustainable-growth topics. Simerini led the group in its reliance on domestic and local sources, while Politis cited the highest proportion of international sources in comparison to the rest of the newspapers. It should be noted that the term "local sources" refers to people linked to the local communities (i.e., local entrepreneurs or regional politicians, such as the mayor of a city), while "domestic/national sources" refer to people with national influence (such as members of the Parliament or national union delegators).

Table 6. Geographical origin of the sources of the reportages (\%)

\begin{tabular}{|l|c|c|c|c|c|}
\hline \multicolumn{1}{|c|}{ Geographical origin } & Simerini & Alithia & Phileleftheros & Politis & Charavgi \\
\hline Local sources & 29.5 & 10.6 & 14.5 & 10.1 & 8.8 \\
\hline Domestic/national & 47.6 & 58.7 & 60.3 & 45 & 67.5 \\
\hline International & 22.3 & 30.2 & 25.2 & 29.6 & 23 \\
\hline Not specified & 0.6 & 0.5 & - & 15.3 & 0.7 \\
\hline Total & 100 & 100 & 100 & 100 & 100 \\
\hline
\end{tabular}

The number of sources each report/news story is based on is also important. As the content analysis indicates (Table 7), the vast majority of the news items in all five newspapers were based on one to three sources. It is remarkable that $15.3 \%$ of the reportages in Charavgi were not based on any (discernible) sources. It is also noteworthy that most of the other newspapers also did print stories without sources, albeit at a lower percentage of their total. Politis seemed to be the only newspaper that did not print reportages without sources, but it is also the newspaper with the highest occurrence of unspecified sources (see above).

Table 7. Sources per reportage (\%)

\begin{tabular}{|l|c|c|c|c|c|}
\hline \multicolumn{1}{|c|}{ Sources number } & Simerini & Alithia & Phileleftheros & Politis & Charavgi \\
\hline No source & 1.2 & 2.1 & 4.7 & - & 15.3 \\
\hline 1 to 3 sources & 69.9 & 77.2 & 78.6 & 50.6 & 66.4 \\
\hline 3 to 6 sources & 26.5 & 19.6 & 15.6 & 42.5 & 15 \\
\hline Over 6 sources & 2.4 & 1.1 & 1.1 & 6.9 & 3.3 \\
\hline Total & 100 & 100 & 100 & 100 & 100 \\
\hline
\end{tabular}


In addition to the number of sources utilized per report, it is important to clarify the types of sources used. Therefore, we investigated the employment of documents (formal/informal documents, etc.) and individuals as sources. As Table 8 outlines, about two thirds of all the reportages in all five newspapers did not mention utilizing documents as sources. Conversely, people seem to be cited (by far) as the dominant sources of information in reportages in all five newspapers, as exhibited in Table 9.

Table 8. Documents as sources for reportages (\%)

\begin{tabular}{|l|c|c|c|c|c|}
\cline { 2 - 6 } \multicolumn{1}{c|}{} & Simerini & Alithia & Phileleftheros & Politis & Charavgi \\
\hline $\begin{array}{l}\text { Documents not } \\
\text { mentioned as sources }\end{array}$ & 63.3 & 58.7 & 65.4 & 77.4 & 79.9 \\
\hline $\begin{array}{l}\text { Documents mentioned } \\
\text { as sources }\end{array}$ & 36.1 & 40.7 & 34.2 & 22 & 20.1 \\
\hline $\begin{array}{l}\text { Sufficient information } \\
\text { not provided }\end{array}$ & 0.6 & 0.6 & 0.4 & 0.6 & - \\
\hline Total & 100 & 100 & 100 & 100 & 100 \\
\hline
\end{tabular}

Table 9. People as sources for reportages (\%)

\begin{tabular}{|l|c|c|c|c|c|}
\cline { 2 - 6 } \multicolumn{1}{c|}{} & Simerini & Alithia & Phileleftheros & Politis & Charavgi \\
\hline $\begin{array}{l}\text { People not mentioned } \\
\text { as sources }\end{array}$ & 8.4 & 18 & 20.5 & 3.8 & 32.8 \\
\hline $\begin{array}{l}\text { People mentioned as } \\
\text { sources }\end{array}$ & 91 & 82 & 99.5 & 96.2 & 67.2 \\
\hline $\begin{array}{l}\text { Sufficient information } \\
\text { not provided }\end{array}$ & 0.6 & - & - & - & - \\
\hline Total & 100 & 100 & 100 & 100 & 100 \\
\hline
\end{tabular}

At this point, it is also important to consider the types/categories of journalistic sources of the news stories. It can be observed in Table 10 that, in Alithia, Charavgi and Phileleftheros, political sources were referenced with the highest predilection in the reportages on sustainable-growth topics, while in Simerini the highest preference was towards experts in the fields relevant to the topic of the story/report. In Politis, political and expert sources seem to be of equal value. In fact, based on the statistical tests, both types of sources seem to have been considered valuable in all five newspapers ( $\mathrm{p}$ value $=0$ ), but it seems that political sources were generally considered more significant ( $\mathrm{z}$ value $>0$ in all newspapers). Less emphasis seems to have been placed on anonymous sources ( $p$ value $>0.05$ and $z$-value $<0$ in most newspapers).

Although financial/corporate sources would have been expected to dominate the specific type of reportage, they appeared at a much lower frequency than the above-mentioned sources, although statistically they seem to have been considered 
Table 10. Thematic origin of sources (\%)

\begin{tabular}{|l|c|c|c|c|c|}
\hline \multicolumn{1}{|c|}{ Theme } & Simerini & Alithia & Phileleftheros & Politis & Charavgi \\
\hline Political sources & 1.3 & 55 & 49.1 & 73.6 & 43.8 \\
\hline Financial/corporate & 19.9 & 22.2 & 12.4 & 31.4 & 3.3 \\
\hline Civic society & 28.3 & 33.9 & 31.6 & 57.2 & 15 \\
\hline Individuals/citizens & 14.5 & 11.6 & 9.8 & 23.3 & 2.2 \\
\hline $\begin{array}{l}\text { Media (news agencies, } \\
\text { foreign media, etc.) }\end{array}$ & 19.9 & 24.3 & 16.7 & 71.1 & 9.1 \\
\hline Experts/specialists & 76.4 & 20.6 & 31.2 & 76.4 & 31.4 \\
\hline Anonymous sources & 20.5 & 12.7 & 15.8 & 4.7 & 5.8 \\
\hline
\end{tabular}

significant ( $\mathrm{p}$ value $=0$ in all newspapers). Anonymous sources constituted the only type identified in the analysis as statistically unimportant in most newspapers ( $\mathrm{p}$ value $>0.05$ ), except in Simerini ( $\mathrm{p}$ value $=0$ ). In fact, Simerini presents an exceptional case, as its news items were dominated by experts as sources ( $\mathrm{z}$ value $=1.98$ ), with civic society sources preferred at the second highest frequency $(z$ value $=0.99)$. Similarly, experts also prevailed as sources in Politis ( $z$ value $=0.93$ ), along with representatives of political institutions $(\mathrm{z}$ value $=1.01$ ).

\section{JOURNALISTS' PERCEPTIONS AND DAILY PRACTICES}

Journalists themselves seem to deem it very important to quote sources that question, criticize or accuse of wrongdoings powerful groups or individuals. As Table 11 shows, $44.3 \%$ of all journalists working in daily newspapers consider this practice very important, although only $24.6 \%$ of them are allowed to perform this way in their daily practice. As the Pearson chi square tests prove, the only factor that is statistically important in this daily practice is the journalist's years of experience, while the journalist's gender and political beliefs play no significant role.

Regarding the freedom journalists enjoy in selecting their own stories and the specific aspects they are going to write about, only $27.9 \%$ of them say that almost always can select the story on which they will work on, while $37.7 \%$ of journalists say that only sometimes they can select themselves the specific aspects of the story they will emphasize on. As Table 12 shows, surprisingly enough, neither the journalists' years of experience nor their gender or political beliefs are statistically important regarding the freedom they enjoy.

Regarding the journalists' beliefs concerning the way (s) they utilize their sources, around half of them consider extremely important the presence of different sources in their stories, the use of hard facts and variable data, the use of quotes of 
Table 11. Journalists' beliefs and practices concerning the importance of quoting criticizing sources

\begin{tabular}{|c|c|c|c|c|c|c|c|c|}
\hline & 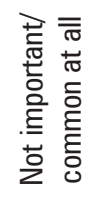 & 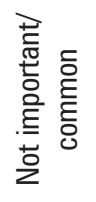 & 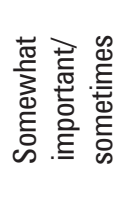 & 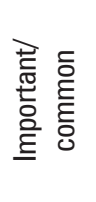 & 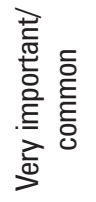 & 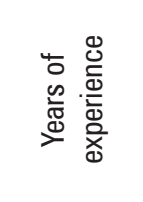 & 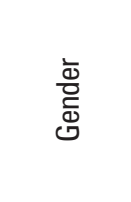 & 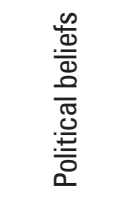 \\
\hline $\begin{array}{l}\text { How much } \\
\text { importance } \\
\text { would you give } \\
\text { to quoting } \\
\text { sources that } \\
\text { question, } \\
\text { criticize or } \\
\text { accuse of } \\
\text { wrongdoings } \\
\text { powerful groups } \\
\text { or individuals? }\end{array}$ & $1.5 \%$ & $23 \%$ & $16.4 \%$ & $14.8 \%$ & $44.3 \%$ & $\begin{array}{l}p=0.007 \\
d f=63 \\
x^{2}=93.5\end{array}$ & $\begin{array}{l}\mathrm{p}=0.306 \\
\mathrm{df}=3 \\
\mathrm{x}^{2}=3.617\end{array}$ & $\begin{array}{l}\mathrm{p}=0.257 \\
\mathrm{df}=27 \\
\mathrm{x}^{2}=31.3\end{array}$ \\
\hline $\begin{array}{l}\text { How common is } \\
\text { the practice of } \\
\text { quoting those } \\
\text { sources in the } \\
\text { news stories you } \\
\text { publish? }\end{array}$ & $1.6 \%$ & $23 \%$ & $18 \%$ & $32.8 \%$ & $24.6 \%$ & $\begin{array}{l}\mathrm{p}=0.730 \\
\mathrm{df}=60 \\
\mathrm{x}^{2}=52.927\end{array}$ & $\begin{array}{l}p=0.637 \\
d f=3 \\
x^{2}=1.700\end{array}$ & $\begin{array}{l}\mathrm{p}=0.307 \\
\mathrm{df}=27 \\
\mathrm{x}^{2}=30.1\end{array}$ \\
\hline
\end{tabular}

Table 12. Journalists' ability to select their stories and/or aspects of news

\begin{tabular}{|c|c|c|c|c|c|c|c|c|c|}
\hline & Never & Seldom & $\begin{array}{l}\text { Some- } \\
\text { times }\end{array}$ & $\begin{array}{l}\text { Almost } \\
\text { always }\end{array}$ & Always & $\begin{array}{c}\text { No } \\
\text { answer }\end{array}$ & $\begin{array}{c}\text { Years of } \\
\text { experi- } \\
\text { ence }\end{array}$ & Gender & $\begin{array}{l}\text { Political } \\
\text { beliefs }\end{array}$ \\
\hline $\begin{array}{l}\text { I have the } \\
\text { freedom to } \\
\text { select the } \\
\text { news/stories } \\
\text { on which } \\
\text { I will work } \\
\text { on }\end{array}$ & $3.3 \%$ & $9.8 \%$ & $23 \%$ & $27.9 \%$ & $14.8 \%$ & $21.3 \%$ & $\begin{array}{l}p=0.670 \\
d f=84 \\
x^{2}=77.79\end{array}$ & $\begin{array}{l}\mathrm{p}=0.447 \\
\mathrm{df}=4 \\
\mathrm{x}^{2}=3.706\end{array}$ & $\begin{array}{l}\mathrm{p}=0.159 \\
\mathrm{df}=36 \\
\mathrm{x}^{2}=44.40\end{array}$ \\
\hline $\begin{array}{l}\text { I have the } \\
\text { freedom to } \\
\text { decide which } \\
\text { aspects of } \\
\text { a news/story } \\
\text { I should } \\
\text { emphasize }\end{array}$ & $6.6 \%$ & $11.5 \%$ & $37.7 \%$ & $11.5 \%$ & $11.5 \%$ & $21.3 \%$ & $\begin{array}{l}\mathrm{p}=0.597 \\
\mathrm{df}=84 \\
\mathrm{x}^{2}=80.19\end{array}$ & $\begin{array}{l}\mathrm{p}=0.208 \\
\mathrm{df}=4 \\
\mathrm{x}^{2}=5.890\end{array}$ & $\begin{array}{l}\mathrm{p}=0.512 \\
\mathrm{df}=36 \\
\mathrm{x}^{2}=35.08\end{array}$ \\
\hline
\end{tabular}

sources and starting a story with the facts before presenting their own opinion. As Table 13 shows, neither the journalists' years of experience nor their gender or 
political beliefs are statistically important regarding the ways they utilize their sources.

Table 13. The ways journalists utilize their sources

\begin{tabular}{|c|c|c|c|c|c|c|c|c|c|}
\hline & 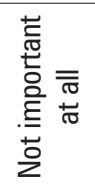 & 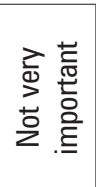 & 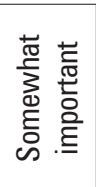 & 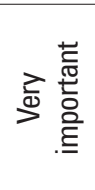 & 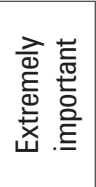 & 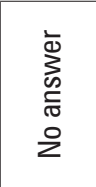 & 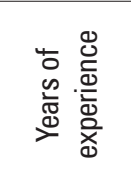 & $\begin{array}{l}\frac{\bar{\Phi}}{0} \\
\text { 임 }\end{array}$ & 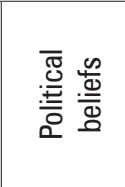 \\
\hline $\begin{array}{l}\text { How important is } \\
\text { the presence of } \\
\text { different sources } \\
\text { in your stories }\end{array}$ & - & $1.6 \%$ & $9.8 \%$ & $16.4 \%$ & $50.8 \%$ & $21.3 \%$ & $\begin{array}{l}\mathrm{p}=0.978 \\
\mathrm{df}=63 \\
\mathrm{x}^{2}=42.55\end{array}$ & $\begin{array}{l}\mathrm{p}=0.568 \\
\mathrm{df}=3 \\
\mathrm{x}^{2}=2.019\end{array}$ & $\begin{array}{l}\mathrm{p}=0.097 \\
\mathrm{df}=27 \\
\mathrm{x}^{2}=36.91\end{array}$ \\
\hline $\begin{array}{l}\text { How important is } \\
\text { the use of hard } \\
\text { facts and variable } \\
\text { data in your } \\
\text { stories }\end{array}$ & - & $6.6 \%$ & $8.2 \%$ & $21.3 \%$ & $42.6 \%$ & $21.3 \%$ & $\begin{array}{l}p=0.343 \\
d f=63 \\
x^{2}=66.95\end{array}$ & $\begin{array}{l}\mathrm{p}=0.399 \\
\mathrm{df}=3 \\
\mathrm{x}^{2}=2.953\end{array}$ & $\begin{array}{l}\mathrm{p}=0.323 \\
\mathrm{df}=27 \\
\mathrm{x}^{2}=29.81\end{array}$ \\
\hline $\begin{array}{l}\text { How important is } \\
\text { the use of quotes } \\
\text { of sources in your } \\
\text { stories }\end{array}$ & - & $3.3 \%$ & $13.1 \%$ & $16.4 \%$ & $45.9 \%$ & $21.3 \%$ & $\begin{array}{l}\mathrm{p}=0.499 \\
\mathrm{df}=63 \\
\mathrm{x}^{2}=62.36\end{array}$ & $\begin{array}{l}\mathrm{p}=0.568 \\
\mathrm{df}=3 \\
\mathrm{x}^{2}=2.020\end{array}$ & $\begin{array}{l}\mathrm{p}=0.570 \\
\mathrm{df}=27 \\
\mathrm{x}^{2}=25.07\end{array}$ \\
\hline $\begin{array}{l}\text { How important is } \\
\text { it to start a story } \\
\text { with facts first } \\
\text { before presenting } \\
\text { your opinion }\end{array}$ & $1.6 \%$ & $4.9 \%$ & $11.5 \%$ & $13.1 \%$ & $47.5 \%$ & $21.3 \%$ & $\begin{array}{l}\mathrm{p}=0.07 \\
\mathrm{df}=84 \\
\mathrm{x}^{2}=103.7\end{array}$ & $\begin{array}{l}\mathrm{p}=0.333 \\
\mathrm{df}=4 \\
\mathrm{x}^{2}=4.578\end{array}$ & $\begin{array}{l}\mathrm{p}=0.341 \\
\mathrm{df}=36 \\
\mathrm{x}^{2}=38.89\end{array}$ \\
\hline
\end{tabular}

\section{CONCLUSIONS}

As indicated by the above results, the reports on topics concerning sustainable growth in the Greek-Cypriot press in 2013 were primarily dependent on political persons/institutions as well as experts (scientists, etc.) in the fields of the reportage ( $\mathrm{z}$ value $>0$ in all newspapers). Expectedly, various newspapers exhibited disparities regarding the frequency of utilization of different types and categories of sources.

These statistical findings, combined with the recurrence of domestic and national sources, indicate that the reportages on issues of sustainable growth seem to have been driven by representatives of political institutions (political parties, government, etc.), possibly as part of their individual communication policy to manage the financial and banking crisis of 2013. Thus, the vast majority of sources used in the national press were domestic, while international sources were of limited use, indicating introspection and lack of attempt to interconnect domestic artifacts with their evolution in the European and/or the international public sphere.

The inconspicuousness in, or even complete lack from, these reports of sources from the financial sector, sources relating directly to the market, sources from civic 
society or individual citizens, as well as the lack of documentation (hard facts and variable data) as sources result in the reduction of diversity of sources and/or opinions. We offer these observations as additional important pieces of evidence in support of our above conclusion.

In addition, we argue that the reduction of diversity of sources, and in particular the underestimation of expert financial and affected social sources, may lead to the manipulation of public opinion and contribute to the formation of a different image for the country by the domestic public opinion in contrast to that prevailing abroad.

The interesting question that arises is whether this can be perceived as an intentional or unintentional process on behalf of the press in times of crisis. As the journalists' questionnaire survey has shown, journalists themselves understand the importance of the utilization of sources in writing their stories. The most important factor in assessing journalistic sources seems to be the journalists' years of experience, while gender or journalists' own political beliefs play no significant role. As expected, journalists' perception of the utilization of sources differs from their daily practices and the amount of freedom allocated to journalists by the news enterprise they work for.

Although the manipulation of public opinion, due to the reduction of the diversity of sources and/or their misuse, has traditionally been attributed to the management policy of media enterprises, this study has shown that journalists themselves are, to a certain extent, responsible for it. This phenomenon may have been the consequence of the special circumstances during the banking crisis the society was experiencing, and not the journalistic perceptions of the utilization of sources. In order to investigate this further, a comparative study should be undertaken, regarding the utilization of journalistic sources before, during and after the banking crisis, in order to assess journalistic performances and roles before, during and beyond the crisis.

\section{REFERENCES}

Bloch-Elkon, Y. (2007). Studying the media, public opinion, and foreign policy in international crises: The United States and the Bosnian Crisis, 1992-1995. The Harvard International Journal of Press/Politics, 12 (4), pp. 20-51.

Byrch, C., Kearins, K., Milne, M., Morgan, R. (2007). Sustainable 'what'? A cognitive approach to understanding sustainable development. Qualitative Research in Accounting \& Management, 4 (1), pp. 26-52. DOI: 10.1108/SRJ-03-2012-0024.

Charalambous, G. (2014). Political Culture and Behaviour in the Republic of Cyprus during the Crisis, Nicosia: PRIO Publications.

Cuadrado-Ballesteros, B., Frias-Aceituno, J., Martínez-Ferrero, J. (2014). The role of media pressure on the disclosure of sustainability information by local governments. Online Information Review, 38 (1), pp. 114-135. DOI: 10.1108/OIR-12-2012-0232.

Curtin, A.P., Rhodenbaugh, E. (2001). Building the news media agenda in the environment: A comparison of public relations and journalistic sources. Public Relations Review, 27, pp. 179-195.

European Parliament Resolution regarding growth and the media. P6_TA 2006/0360 (INI). (In Greek). 
Griffin, J.R., Dunwoody, S. (1995). Impacts of information subsidies and community structure on local press coverage of environmental contamination. Journalism \& Mass Communication Quarterly, 72, pp. 271-284.

Herman, E.S., Chomsky, N. (2002). Manufacturing Consent: The Political Economy of the Mass Media. New York: Pantheon.

Hermans, L., Vergeer, M. (2009). Internet in the daily life of journalists: Explaining the use of the Internet by work-related characteristics and professional opinions. Journal of Computer-Mediated Communication, 15, pp. 138-157.

International Monetary Fund (IMF) (2014). Annual Report 2014 - From Stabilization to Sustainable Growth. Washington: IMF.

Kollmeyer, J.C. (2004). Corporate interests: How the news media portray the economy. Social Problems, 51 (3), pp. 432-452.

Lacy, S., Coulson, C.D. (2000). Comparative case study: Newspaper source use of the environmental beat. Newspaper Research Journal, 21 (1), pp. 13-25.

Leandros, N. (2012a). Communication power: The changing role of media in the digital era. Paper presented in International Autumn School Mediterranean Security 2012 on Security in the Mediterranean: Old Conflicts - New Challenges, organized by Panteion University, Aegean University and Neapolis University, Paphos, September 23-30.

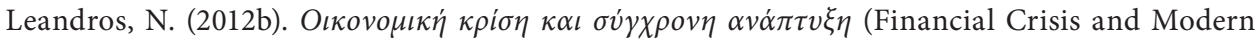
Growth). Athens: Dionikos (In Greek).

Lee, M. (1999). Reporters and bureaucrats: public relations counter-strategies by public administrators in an era of media disinterest in government. Public Relations Review, 25 (4), pp. 451-463.

Lewis, L.T. (2000). Media representations of 'sustainable development'. Science Communication, 21 (3), pp. 244-273.

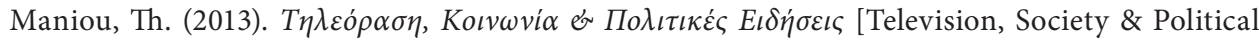
News]. Athens: Epikentro.

Mellado, C., Lagos, C. (2014). Professional roles in news content: Analyzing journalistic performance in the Chilean national press. International Journal of Communication, 8, pp. 2090-2112.

Pawson, R. (1995). Methods of content/document/media analysis. In: Haralambo, M. (ed.). Developments in Sociology. Ormskirk: Causeway Press, pp. 107-128.

PRIO group (ed.) (2010). Media Narratives, Politics and the Cyprus Problem. Nicosia: PRIO Cyprus Centre.

Quinn, S. (1999). Internet availability and adoption at Australian daily newspapers, 1997-99. Communication Research Forum Papers, 2, pp. 319-330.

Stefanou, C. (2011). The banking system in Cyprus: Time to rethink the business model? Cyprus Economic Policy Review, 5 (2), pp. 123-130.

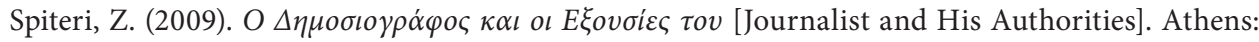
Kastaniotis.

The G20 Toronto Summit Declaration (2010, June 26-27). Toronto (press release).

Trumbo, C.W., Sprecker, K.J., Dumlao, R.J., Yun, G.W., Duke, S. (2001). Use of e-mail and the web by science writers. Science Communication, 22 (4), pp. 347-378.

Wilenius, M., Malmelin, N. (2009). Towards sustainably managed media organizations: Reflections on the future of responsible business in media industry. Business Strategy Series, 10 (3), pp. 129 138.

Witschge, T., Nygren, G. (2009). Journalism: A profession under pressure? Journal of Business Studies, 6 (1), pp. 37-59.

Witt, W. (1974). The environmental reporter on US daily newspapers. Journalism Quarterly, 51, pp. 697-704. 